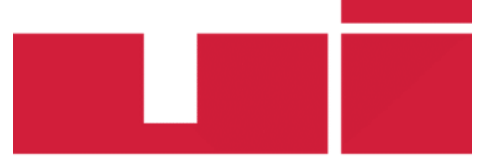

\title{
20 Years of Securitization:
}

\section{Strengths, Limitations and A New Dual Framework}

\author{
Basar BAYSAL \\ Dr., Postdoctoral Research Fellow, Universidad Del Rosario, Faculty of International, \\ Political and Urban Studies
}

To cite this article: Basar Baysal, "20 Years of Securitization: Strengths, Limitations and A New Dual Framework", Uluslararasi Iliskiler, Vol. 17, No. 67, 2020, pp. 3-20, DOI: $\underline{10.33458 / \text { uidergisi.777338 }}$

To link to this article: https://dx.doi.org/10.33458/uidergisi.777338

Submitted: 03 October 2019

Last Revision: 01 July 2020

Published Online: 31 July 2020

Printed Version: 01 September 2020

\section{Uluslararası İlişkiler Konseyi Derneği | International Relations Council of Turkey \\ Uluslararası İlişkiler - Journal of International Relations \\ E-mail : bilgi@uidergisi.com.tr}

All rights of this paper are reserved by the International Relations Council of Turkey. With the exception of academic quotations, no part of this publication may be reproduced, redistributed, sold or transmitted in any form and by any means for public usage without a prior permission from the copyright holder. Any opinions and views expressed in this publication are the author(s)'s and do not reflect those of the Council, editors of the journal, and other authors. 


\title{
20 Years of Securitization: Strengths, Limitations and A New Dual Framework
}

\author{
Başar BAYSAL \\ Dr., Postdoctoral Research Fellow, Universidad Del Rosario, Faculty of International, Political and Urban Studies, Bogota, Colombia \\ E-mail:bbaysal85@gmail.com
}

\begin{abstract}
Copenhagen School scholars introduced Securitization Theory in 1998 in a comprehensive way. Since then, it has been used widely to examine diverse topics. The strength of the theory derives from its constructivist ontology and clear framework. However, the theory has various limitations including lack of the analysis of rival views. This study aims to outline the strengths and limitations of Securitization Theory and present a novel framework for securitization. The new framework provides a dual approach for examining non-violent oppositions and counter-securitizations. It also analyses the securitization process in three phases: decision/ definition, construction, and insecuritization-in-action.
\end{abstract}

Keywords: Dual Securitization, Insecuritization, Security Professionals, Counter-Securitization, Critical Security Studies

\section{Güvenlikleştirmenin 20 Yılı: Gücü, Sınırları ve Yeni Bir İkili Analiz Çerçevesi}

ÖZET

Kopenhag Okulu yazarları Güvenlikleştirme Teorisi’ni kapsamlı olarak 1998 yılında ortaya koymuşlardır. Sonrasında teori birçok farklı konunun incelenmesinde kullanılmıştır. Teorinin gücü açık ve pratik bir analiz çerçevesi sunması ve inşacı ontolojisinden kaynaklanmaktadır. Ancak teorinin karşıt görüşlerin analiz edilmemesi gibi birtakım eksiklikleri de mevcuttur. Bu çalışma Güvenlikleştirme teorisinin güçlü ve zayıf yanlarını analiz ederek, yeni bir ikili güvenlikleştirme çerçevesi ortaya koymayı hedeflemektedir. Bu yeni analiz çerçevesi güvenlikleştirmeye karşı olan, şiddet içermeyen muhalif görüşleri ve karşıt güvenlikleştirmeleri inceleme imkanı sunmaktadır. Bunun yanında ikili güvenlikleştirme yaklaşımı güvenlikleştirmeyi tanımlama, inşa ve güvenliksizliklerin ortaya çıkışı olmak üzere üç temel safhada incelenmektedir.

Anahtar Kelimeler: İkili Güvenlikleştirme, Güvenliksizleştirme, Güvenlik Profesyonelleri, Karşıt Güvenlikleştirme, Eleştirel Güvenlik Çalışmaları 


\section{Introduction}

In the last quarter of the twentieth century, due to dissatisfaction with the narrow, state-centric, and military-oriented approach of traditional security studies, new approaches to security started to emerge under the general topic of critical security studies. ${ }^{1}$ These new approaches both widened and deepened security studies both by adding new issues like the environment and economics, and new levels like individual human beings and global security. Within this scholarship, one of the most cited approaches is the Securitization Theory of the Copenhagen School. Although its roots can be traced back to $1983,{ }^{2}$ its clearest and the most comprehensive introduction was presented in Security: A New Framework for Analysis in 1998. ${ }^{3}$ Since then, the theory has been used to explain various issues, including terrorism, violent conflict, intervention, climate change, migration, minority issues and epidemiological threats like HIV-AIDS. ${ }^{4}$

To analyze how security issues are constructed, Securitization Theory focuses on the speech acts of political elites. ${ }^{5}$ The elites convince the audience that an issue is an existential security threat to a referent object that must be protected. They thereby legitimize the subsequent implementation of extraordinary measures to overcome this threat. However, despite its popularity, Securitization Theory has various limitations, some of which are identified by different scholars. ${ }^{6}$ These include a lack of analysis of rival views (i.e. attention to rival voices and counter-securitizations), overemphasis of speech acts and under-analysis of non-discursive practices, an elitist framework, a decisionist approach that assumes that securitization occurs at the moment when the audience accepts the securitizing actor's proposal, the framework's Eurocentric perception, under analysis of audience and contextual factors, and overemphasis on macro-level discourses while ignoring micro-level practices. This study outlines the strengths and limitations of Securitization Theory and presents a dual framework for securitization. $^{7}$

1 C.A.S.E. Collective, “Critical Approaches to Security in Europe, A Networked Manifesto", Security Dialogue, Vol. 37, No 4, 2006, p. 443-487; Neslihan Dikmen-Alsancak, "Üçüncü Dünya Güvenlik ve Postkolonyal Güvenlik Yaklaşımları Aransındaki Farklılıklar: Devlet, Kültür ve Modernite”, Uluslaralası İlişkiler, Vol. 16, No 63, 2019, p. 13-31.

2 Barry Buzan, People States and Fear: An Agenda for International Security Studies in the Post- Cold War Era, Brighton, Wheatsheaf Books, 1983.

3 Barry Buzan, Ole Wæver, and Jaap De Wilde, Security: A New Framework for Analysis, Boulder, Lynne Rienner Pub., 1998.

4 Mark Salter, “Securitization Theory: 20 Years in Security Dialogue”, Security Dialogue, Virtual Special issue, https:// journals.sagepub.com/pb-assets/cmscontent/SDI/Securitization\%20Theory.pdf (Accessed 17 January 2019).

5 Buzan et al.,Security: A New Framework.

6 Thierry Balzacq, “The Three Faces of Securitization: Political Agency, Audience and Context”, European Journal of International Relations, Vol. 11, No 2, 2005, p. 171-201; Thierry Balzacq, Securitization Theory: How Security Problems Emerge and Dissolve, Abingdon, Routledge, 2011; Matt McDonald, "Securitization and the Construction of Security", European Journal of International Relations, Vol. 14, No 4, 2008, p. 563-587; Michael C. Williams, "Words, Images, Enemies: Securitization and International Politics”, International Studies Quarterly, Vol. 47, No 4, 2003, p. 511-531; Ken Booth, Theory of World Security, Cambridge, Cambridge University Press, 2007. Basar Baysal, Securitization and Desecuritization of FARC in Colombia, New York, Lexington Books, 2019; Lene Hansen “The Little Mermaid's Silent Security Dilemma and the Absence of Gender in the Copenhagen School", Millennium - Journal of International Studies, Vol. 29, No 2, 2000, p. 285-306; Claire Wilkinson, "The Copenhagen School on Tour in Kyrgyzstan: Is Securitization Theory Useable Outside Europe?”, Security Dialogue, Vol. 38, No 1, 2007, p. 5-25; Pinar Bilgin, “The Politics of Studying Securitization? The Copenhagen School in Turkey", Security Dialogue, Vol. 42, No 4-5, 2011, p. 399-412; Juha Vuori, How to Do Security with Words: A Grammar Of Securitization in The People's Republic of China, Unpublished PhD Dissertation, Turku, University of Turku, 2011.

7 I use securitization with lower case 's' to refer to the construction of security issues in general and Securitization with an upper case 'S' to refer to the Copenhagen School's Securitization approach, which has a specific analytical framework. 
The new framework addresses some of the above-mentioned limitations while introducing a broader perspective for examining the construction of security issues. It regards securitization as a process, which is examined in three phases: definition, construction, and insecuritization-in-action. It also considers non-discursive practices in addition to speech acts and examines the role of high-level decision-makers and security professionals. Moreover, it provides a dual framework to examine rival voices and counter-securitizations in a securitization process. Finally, in addition to the process of securitization, it focuses on the insecuritizing consequences of this process. For these contributions, the new framework feeds from the insights of two other prominent approaches within critical security studies, namely the Welsh School's Emancipatory Security approach and the Paris School's International Political Sociology approach.

Although this article does not present a full-fledged case study, in order to clarify the assumptions of the new dual framework, I used the case of Revolutionary Armed Forces of Colombia (Fuerzas Armadas Revolucionarias de Colombia - FARC). The conflict between FARC and the Colombian state started in the 1960s. Since then, both sides securitized each other and used violent means. FARC was founded as an insurgent guerrilla group to protect the poor peasants in Colombia. With the impact of drug trafficking and the emergence of paramilitary groups, in addition to the weakness of the state apparatus in some parts of the country, the conflict escalated rapidly after the 1980s. Many insecurities emerged because of the conflict, including the death of civilians, recruitment of child combatants, forced migration, forced disappearances, sexual abuse and limitation of freedoms like freedom of speech. During the late 1990s, FARC was controlling some parts of the country. Despite the peace agreement that was signed in 2016, the conflict can be regarded as continuing, since the issue is not fully desecuritized yet. Recent developments in Colombia, including the death of ex-militants and the emergence of dissident groups, also made it clear that the dual securitization process continues. As this case is a clear example of a dual securitization, I used it to present the assumptions of the dual securitization framework. In the following parts, the dual character, phases and the actors of the dual securitization of FARC and the Colombian state are also examined briefly.

\section{Securitization Theory: Strengths and Limitations}

Securitization theory has become one of the most frequently used security approaches in the last 20 years since it was fully developed in $1998 .{ }^{8}$ According to this theory, issues are prioritized and constructed as security threats via speech acts whereby the securitizing actor convinces the audience that the given issue is an existential threat to a referent object that must be protected. Once an issue is securitized, it becomes the top priority, and extraordinary measures against this threat are legitimized.

The Copenhagen School scholars define securitization as an extreme version of politicization. ${ }^{9}$ By securitizing specific issues, the securitizing actor takes these issues out of the political sphere into the sphere of security. This explanation can be summarized in the following diagram:

8 Buzan et al., A New Framework.

9 Ibid., p. 23-24. 


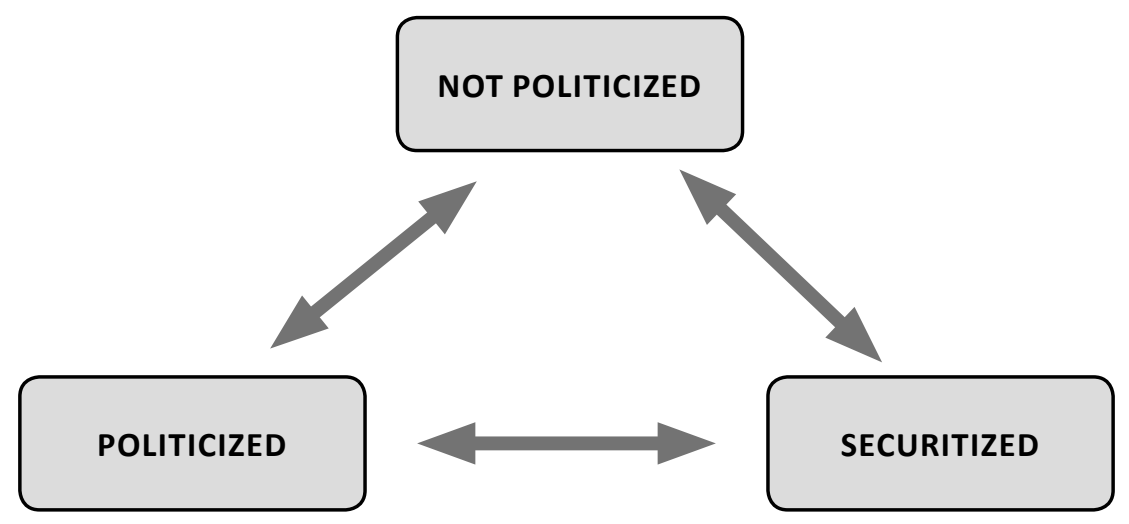

Un-politicized issues are considered to be within the technical/private realm, outside the public political debate, whereas they become part of public-political debate once they have been politicized. When issues are securitized, they are said to fall into a special category of existential threats. They gain a unique character based on a friend-enemy dichotomy and urgency. These threats are prioritized because of the assumption that unless they are dealt with, their referent objects are in existential danger. This, therefore, legitimizes the use of extraordinary measures against them. Securitization of an issue also hinders public-political debate because the security realm has its own mentality, means, and dynamics. Securitization Theory regards desecuritization as a long-term goal normatively, arguing that issues should be solved within the political realm where political debate and discussion are possible. ${ }^{10}$

Securitization Theory adopts a constructivist ontology, according to which security issues are not necessarily objective but constructed. The roots of the theory can be found in the language theory of Austin. ${ }^{11}$ The Copenhagen School scholars argue that security issues are inter-subjectively constructed. ${ }^{12}$ In line with this, the most crucial aspect of the construction of security issues is the use of the grammar of security, which enables the securitizing actor to create a plot that includes an existential threat, a point of no return, and a way out. ${ }^{13}$ According to Juha A. Vuori, Securitization Theory is perhaps the most systematic approach for examining the influence of security arguments: ${ }^{14}$

"The study of securitization does not mean the assessment of some objective threats that 'really' endanger something; this would require an objective measure of security, which no security theory has been able to provide. Instead, this theory is a means to understand the processes of constructing a shared understanding of what is to be considered and collectively responded to as a threat. Security is a self-referential practice; it is by labeling something as a security issue that it becomes one."

Despite its philosophical background, the most important strength of Securitization Theory derives from its clear and practical framework. This is also the main reason for its attractiveness

10 Ibid., p. 8; Arlene B. Tickner, "Securitization and the Limits of Democratic Security", David Mares and Arie M. Kacowicz (eds.), Routledge Handbook of Latin American Security, New York, Routledge, 2015, p. 67-77.

11 J. L. Austin, How to Do Things with Words, Oxford, Oxford University Press, 1975.

12 Buzan et al., Security: A New Framework, p. 8.

13 Ibid., p. 32.

14 Vuori, How to Do Security with Words, p. 106. 
and popularity. With the help of the framework, analysts can determine how different issues are constructed as security issues through the speech acts of securitizing actors. It also provides a clear path for the examiners by presenting clear-cut questions for the analysis: "who securitizes (securitizing actor), on what issues (threats), for whom (referent object), why, with what results, and not least, under what conditions". ${ }^{15}$ The analyst investigates the units of the process (securitizing actor, referent object and functional actors) and examines the speech acts of the securitizing actor to identify how they convinced their audience that the given issue is an existential threat to the referent object.

Despite its strengths and popularity in the last 20 years, Securitization Theory has several limitations, some of which have already been identified by different scholars. The most criticized aspect is its focus on speech acts. ${ }^{16}$ According to McDonald, the theory over-emphasizes speech acts while neglecting other processes or means for communication, such as images and other visual representations like videos, which also play a significant role in the process. ${ }^{17}$ As Möller notes, "language is only one of the (albeit the most central) means, through which meaning is communicated". ${ }^{18}$ Moreover, Williams emphasizes the importance of images by stating that: "Security policies today are constructed not only with the question of their linguistic legitimation in mind; they now are increasingly decided upon in relation to acceptable image-rhetorics." ${ }^{19}$ Addressing these criticisms, several studies have examined the impact of other means of communication during the securitization process. ${ }^{20}$ In line with this, the dual framework that is introduced in this article also takes different means of communication into account in addition to speech acts.

In addition to images and other visual representations, Paris School scholars also emphasize the role of the practices of security professionals, ${ }^{21}$ arguing that these play a more crucial role than discursive practices in constructing security issues. ${ }^{22}$ That is, rather than the magical power of speech acts, it is the institutionalizations and routinizations through repetitions of security practices that produce security issues. ${ }^{23}$ Moreover, unlike the Copenhagen School, scholars of the Paris School also focus on the insecuritizing consequences of the process of securitization by asking what security does rather than what security is. ${ }^{24}$ In this way, they also inquire and focus on the threats that ordinary

15 Buzan et al., Security: A New Framework, p. 32.

16 For the critique of the overemphasis of discourse in general see Klevis Kolasi, "Postyapısalcılı̆gin Söylemsel Ontolojisinin Eleștirisi: Uluslararası Ilişskilerde Söylem Dıșı Alan ve Eleștirel Gerçekçilik”, Uluslararası Ilişkiler, Vol. 17, No 65, 2020, p. 83-100.

17 McDonald, "Securitization and the Construction of Security", p. 568.

18 Frank Möller, “Photographic Interventions in Post-9/11 Security Policy”, Security Dialogue, Vol. 38, No 2, 2007, p. 180

19 Williams, "Words, Images, Enemies”, p. 527; See also Hansen, “The Little Mermaid's Silent Security Dilemma”.

20 Fred Vultee, "Securitization as a Media Frame", Thierry Balzacq (ed.), Securitization Theory: How security problems emerge and dissolve, New York: Routledge, 2010, p. 77-93; Basar Baysal, "Coercion by Fear: Securitization of Iraq Prior to the 2003 War”, International Journal, Vol. 74, No 3, 2019, p. 363-386.

21 Columba Peoples and Nick Williams, Critical Security Studies: An Introduction, Abingdon, Routledge, 2010, p. 69.

22 C.A.S.E. Collective, "Critical Approaches to Security in Europe”, p. 448; Peoples and Williams, Critical Security Studies.

23 Balzacq, Securitization Theory, p. 13; Delf Rothe, Securitizing Global Warming: A Climate of Complexity, Abingdon, Routledge, 2016, p. 21.

24 Didier Bigo, "International Political Sociology”, Paul D. Williams (ed.), Security Studies: An Introduction, Abingdon, Routledge, 2008, p. 116; Didier Bigo and Anastasia Tsoukala, "Understanding (In)Security”, Didier Bigo and Anastasia Tsoukala (eds.), Terror, Insecurity and Liberty: Illiberal Practices of Liberal Regimes After 9/11, Abingdon, Routledge, 2008, p. 2. 
people face, like the Welsh School does, with its Emancipatory Security approach. ${ }^{25}$ However, the Paris School is also limited since it overemphasizes micro-level practices and ignores macro-level decisionmaking with its bottom-up framework. ${ }^{26} \mathrm{My}$ dual framework borrows insights from the approach of the Paris School as it takes the practices of security professionals into account without ignoring the discursive impact of speech acts of macro-level decision-makers. Moreover, it also focuses on the insecuritizing consequences of securitization.

Another significant limitation of Securitization Theory is the inadequate analysis of the audience. According to Thierry Balzacq, the role of the audience is underspecified because of Wæver's reliance on John L. Austin's language theory. ${ }^{27}$ I additionally argue that the overemphasis on speech acts and under-analysis of the audience(s) in the framework of Securitization Theory derives from the tendency of the Copenhagen School scholars to see securitization as a universal phenomenon. According to Balzacq, however, "the success of securitization is highly contingent upon the securitizing actor's ability to identify the audience's feelings, needs, and interests... To persuade the audience, the speaker has to tune his/her language to the audience's experience." 28

Securitization Theory also fails to adequately analyze contextual issues. Balzacq, for example, claims that whereas Securitization Theory claims that securitization modifies the external context, the opposite is also true: the contextual issues and audience characteristics also influence the process and success of securitization..$^{29}$ According to Matt McDonald, "in developing a universal framework for the designation or construction of threat through speech acts, the Securitization Theory ultimately downplays the importance of contextual factors." ${ }^{30}$ Attention to these two related limitations, concerning audience and context, is essential to the dual securitization framework too. However, I do not elaborate on these in this article since they have already been discussed by various scholars, and many empirical studies have already been conducted with a focus on these issues. ${ }^{31}$

Another related limitation is the Copenhagen School's Eurocentric perspective. Securitization is about the construction of exception. In a way, securitization is exceptionalization of an issue to use extraordinary measures against it. However, this raises the important question of what normal is. Since normal itself has temporal and spatial dimensions, exceptions and exceptionalization also vary across time and place, such that an exceptional issue in one time and place may be regarded as normal in another. Therefore, there may be different mechanisms, measures, difficulties, and consequences in the securitization processes in different contexts. ${ }^{32}$ However, the inclusion of contextual and audience analysis to the securitization by Balzacq and other second-generation securitization scholars mostly

25 Bigo, "International Political Sociology"; Bigo and Tsoukala, "Understanding (In)Security"; Rita Floyd, "Towards a Consequentialist Evaluation of Security: Bringing Together the Copenhagen and Welsh Schools of Security Studies", Review of International Studies, Vol. 33, No 2, 2007, p. 327-50

26 Ole Wæver, “The Theory Act: Responsibility and Exactitude as Seen from Securitization”, International Relations, Vol. 29, No 1, 2015, p. 125; Rothe, Securitizing Global Warming, p. 22.

27 Balzacq, “The Three Faces of Securitization”, p. 173.

28 Ibid., p. 184.

29 Ibid., p. 182.

30 McDonald, "Securitization and Construction of Security", p. 571.

31 Balzacq, "The Three Faces of Securitization"; McDonald, "Securitization and Construction of Security"; Baysal, Coercion by Fear.

32 Wilkinson, “The Copenhagen School”; Hansen, “The Little Mermaid's Silent Security Dilemma”; Bilgin, "Politics of Studying Securitization"; Baysal, Securitization and Desecuritization of FARC; Peoples and Williams, Critical Security Studies. 
solved this problem, and there are many securitization studies outside the West. ${ }^{33}$ This study also contributes to overcoming this limitation by presenting how different types of rival stances emerge in different contexts.

Howell and Richter-Montpetit have taken this criticism of Eurocentrism one step further and presented Securitization as racist. ${ }^{34}$ They argued, in Securitization Theory, what is normal is regarded as European norms and regarded securitization and the Copenhagen School as racist by referring to its reference to desecuritization as the favorable route. However, the arguments of Howell and Richter-Montpetit are problematic. First of all, Eurocentrism can not be regarded as racism. As stated above, this problem of Eurocentrism has already been solved too. Additionally, their arguments are problematic since they refer to Buzan and Wæver's 2003 book, which is related to the Regional Security Complex (RSC) Theory rather than securitization. ${ }^{35}$ Although the security relations in Africa are presented as conflict-prone in this study, this does not make the Copenhagen School racist, since their RSC Theory is not based on ethnicity. Moreover, the authors cherry-pick sentences and twist concepts to prove their arguments.

Another shortcoming of the Securitization Theory is its elitism and top-down framework. In line with the Schmittian roots of Securitization Theory, it is implicitly elitist since it elevates political leaders and decision-makers while regarding others as the passive listeners/audience that can only accept (or reject) securitization. It does this by presenting securitization as a top-down, linear process while neglecting the bottom-up characteristics of the process. ${ }^{36}$ However, I argue that a securitization process has both top-down and bottom-up characteristics, and in a securitization analysis, all of these characteristics should be taken into consideration.

In addition, by focusing on the illocutionary act, securitization is presented as happening within a single moment rather than as a process over time. Ole Wæver, for example, argues "the utterance itself is the act ... by uttering security, a state representative moves a particular development into a specific area, and thereby claims a special right to use whatever means to block it." ${ }^{37}$ That is, securitization occurs just within the moment when the speech act is performed, and the audience has accepted it. ${ }^{38}$ Although this Schmittian stance has somewhat changed in the 1998 book $^{39}$ by focusing on the securitizing move and the inherent processual nature of persuasion of the audience, the processual understanding of securitization is still limited. Still, in this framework of the Copenhagen School (successful) securitization ends with the persuasion of a sufficient number of right people and

33 Bilgin, "Politics of Studying Securitization", p. 401.

34 Alison Howell and Melanie Richter-Montpetit, "Is Securitization Theory Racist? Civilizationism, Whiteness, and Antiblack Thought in the Copenhagen School”, Security Dialogue, Vol. 51, No1, 2019, p. 3-22.

35 Barry Buzan and Ole Wæver, Regions and Powers, Cambridge, Cambridge University Press, 2003.

36 Booth, Theory of World Security. According to the Copenhagen School scholars, although non-elites can also perform securitization, in practice and in most of the case studies, it is the elites who are securitizing actors. Moreover, the Copenhagen School scholars accept that the securitizing actor should have some features like the reach of means of communication for the success of securitization, and these features identify the political elites as the securitizing actors.

37 Ole Wæver, "Securitization and Desecuritization", Ronnie D. Lipschutz (ed.), On Security, New York, Columbia University Press, 1995, p. 55.

38 Balzacq, Securitization Theory, p. 3; McDonald, “Securitization and the Construction of Security”, p. 576; Holger Stritzel, “Towards a Theory of Securitization: Copenhagen and Beyond”, European Journal of International Relations, Vol. 13, No 3, 2007, p. 357-383; Rothe, Securitizing Global Warming, p. 21.

39 Buzan et al., Security: A New framework. 
the start of the extraordinary measures. ${ }^{40}$ However, I argue that securitization should be considered as a process that includes the definition of security, discursive efforts to convince the audience, security practices that normalize and routinize the security definition, the clashes between rival security definitions and arguments, and the insecurities that result from these security practices. I further argue that securitization lasts until the issue is fully desecuritized. It can further be argued that securitization and desecuritization may occur simultaneously; some groups may be struggling to securitize an issue, while others may be working for its desecuritization.

The main shortcoming of Securitization Theory relevant for the argument of this study is the lack of the analysis of rival voices. Securitization is considered as truth construction. That is, the Securitizing actor proposes a truth claim and convinces audiences of this claim. The securitizing actor proposes a security definition in which s/he describes the threat, legitimate security provider, referent object, and legitimate means to deal with the issue. However, there are always rivals who reject this truth claim or, in most cases, counter truth claims, and definitions emerge. This a constant conflict between these truth claims, while constructing security issues means that a securitization analysis should also examine these rival voices. These rival voices may take the form of non-violent opposition or counter-securitization. To overcome this limitation, a dual approach is required to examine rival voices in the securitization process.

The lack of a dual approach in Securitization Theory means that a securitization analysis can only problematize one side, namely that of the securitizing actors, by revealing how they create security issues and use security discourses to achieve their own aims. In most cases, this actor is the state or other formal institutions like the EU. In most cases, however, particularly when counter-securitization emerges, other securitizing actors are involved that should also be problematized. These may also use extraordinary or violent means like the use of force. For example, in the securitization of a minority group in a country, the state may be the securitizing actor, which uses extraordinary means as a result of a securitization process. However, there may also be a counter-securitization against the state from within this minority group, and this securitizing actor may also be using extraordinary means against the state like the use of force. The sequence of the primary and counter-securitization may also change. Hence, both primary and counter-securitizations should be investigated in a comprehensive securitization analysis. However, it should be stated that there does not have to be a countersecuritization in all securitization cases. There may also be non-violent opposition depending on the contextual factors, but I argue that there are always rival voices in line with the argument of Foucault that "where there is power there is resistance." 41

The new framework presented in this article addresses some of the above criticisms to derive a broader analysis of the construction of security issues and their consequences. In addition to speech acts, the new framework integrates non-discursive practices and other means to convey meaning such as maps, images and other visual representations. It examines the differing roles of high-level decision-makers and security professionals with a particular focus on their discursive efforts and non-discursive practices, respectively. It regards securitization as a process rather than a one-moment event by analyzing the process in three phases: definition, construction, and insecuritization-in-action. It introduces a dual framework to examine primary securitization,

40 Baysal, "Coercion by Fear".

41 Michel Foucault, History of Sexuality, New York, Pantheon Books, 1978, p. 95-96. 
counter-securitization, and non-violent opposition, while problematizing both sides of political debate. Finally, the framework investigates the insecuritizing consequences of the process as an integral part of the analysis.

\section{The New Dual Framework for Securitization}

I regard securitization as a process of truth production behind which there are always interests and relations of power. In analyzing securitization, the new approach aims to lay bare the processes underlying this meaning/truth production and demonstrate how the security practices that are performed in accordance with these truth claims produce insecurities for ordinary people.

\section{The Dual Nature of Securitization}

Securitization is not the linear process posited by Securitization Theory, as there are always rival voices and resistant stances. These rival voices create constant debate during the process of securitization, even after the start of extraordinary measures. Securitization analysis should, therefore, take rival stances into consideration. Rival voices can take two different forms depending on the context. In some instances, only non-violent opposition may emerge, which may have a rival security definition or simply reject the security definition proposed by the securitizing actors. In other instances, these rival voices can take the form of counter-securitization that includes violent resistance. Thus, the securitization analysis must be conducted in a dual manner that considers both sides of the political debate. Specifically, if there is counter-securitization, both the primary securitization and the countersecuritization must be examined.

Although several scholars have used the term counter-securitization before, ${ }^{42}$ they did not elaborate on the concept and situated it as an inseparable part of securitization analysis. In most cases, counter-securitization is presented as a resistance move, and the term is particularly used to differentiate these resistant actions from desecuritization. Counter-securitization emerges as a resistant counter move against the securitizing move of the primary securitization. In this move, in addition to rejecting and resisting the securitization argument of the primary securitizing actor, the counter-securitization move also securitizes this actor. It presents the primary securitizing actor as a security threat, and it proposes and, if accepted by the relevant audience, takes extraordinary measures against it. There are similar units like the securitizing actor, referent object, and audience in the counter-securitization process too. However, it should be kept in mind that, either primary or counter-securitization might rely more on security practices than security discourses, since one side may be disadvantaged to reach means of communication.

42 Claudia Aradau, "Security and the democratic scene: desecuritization and emancipation", Journal of International Relations and Development, Vol. 7, No 4, 2004, p. 388-413; Lene Hansen, "De-securitization, Counter-securitization, or Visual Insurgency? Exploring Security Discourses through Responses to the Muhammad Cartoons”, Paper presented at the fifty-first Annual Convention of the International Studies Association, New Orleans, February 17-20, 2015; Thierry Balzacq, Sara Depauw and Sarah Leonard, “The Political Limits of Desecuritization: Security, Arms Trade, and the EU’s Economic Targets”, Thierry Balzacq (ed.), Contesting Security: Strategies and Logics, London and New York, Routledge, 2015, p. 104-121; Juha Vuori, "Contesting and Resisting Security in Post-Mao China”, Thierry Balzacq (ed.), Contesting Security: Strategies and Logics, London and New York, Routledge, 2015, p. 29-40; Holgar Stritzel and Sean C Chang, "Securitization and Counter-Securitization in Afghanistan", Security Dialogue, Vol. 46, No 6, 2015, p. 548-567. 
Non-violent opposition also rejects and resists the securitization argument of the primary securitization. However, in this case, the primary securitizing actor is not securitized. This move can be considered more like a desecuritization move that takes place during the securitization process. However, I do not define this move as desecuritization, since the scope of desecuritization is much broader and includes different moves like the deconstruction of securitized identities and the prevention of the escalation of securitization in addition to the non-violent opposition that takes place during a securitization process.

Since there are always rival voices in a securitization process that can take two forms as argued above, a securitization analysis must be conducted in a dual manner, which will take both sides of the political debate into consideration. If there is only non-violent opposition without countersecuritization, the efforts and impact of this opposition must be examined in the securitization process. However, if there is a counter-securitization, both the primary securitization and the countersecuritization must be examined with the analysis of all phases and units that are given in the following part of the study. Moreover, these two, counter-securitization and non-violent opposition can also emerge simultaneously, and if there is a counter-securitization, there may also emerge non-violent opposition too.

In the Colombian case, the process started when the Colombian government started to securitize the communist factions in the country after the La Violencia era in the 1960s. The United States also played an essential role as a functional actor in this securitization process, as the issue took place in the early period of the Cold War. However, this process of securitization can not be examined by only analyzing this primary securitization move. The communist factions also responded with a counter-securitization by forming armed guerrilla groups like FARC. That is, each side presented the other as an existential security threat and then used extraordinary means. Therefore, to be able to thoroughly investigate the case of FARC using the approach of securitization, an analyst needs to examine both the primary securitization and the counter-securitization. ${ }^{43}$

In this case, in addition to the primary and counter-securitizations, non-violent opposition emerged against both primary and counter-securitizations too. Non-governmental organizations, political parties, human rights activists, and peace supporters in Colombia rejected the securitization arguments of either or both sides. For example, in 1985, a political party, namely Patriotic Union (Union Patriotica - UP) was founded as a legal body, and it criticized the securitization moves and security practices of the Colombian government without securitizing it. However, most of the members of this political party were killed by the paramilitary groups. Many NGOs, particularly indigenous groups who suffered most from the conflict, also acted as a rival body to both securitizations. ${ }^{44}$

43 Baysal, Securitization and desecuritization of FARC. For the Colombian case, some may argue that it was not the Colombian state but the FARC which first securitized the other side and the Colombian state reacted with a countersecuritization. I attribute this political discussion to the epistemological character of the securitization approach, which does not separate the researcher from the research itself.

44 Ibid. 


\section{The High-Level Decision Makers and Security Professionals}

The importance of security professionals as actors in the security field has been emphasized by the Paris School scholars and constitutes an integral part of its insecuritization approach. ${ }^{45}$ According to its insecuritization approach, securitization is an effect emerging from the field of security professionals, and it does not result from a strategy of a dominant actor. ${ }^{46}$ The security professionals' practices lead to the construction of security issues, and their expert position is crucial for this construction. However, I argue that both high-level decision-makers and security professionals have an impact on the construction of security issues. In line with this stance, the new framework examines the differing roles of high-level decision-makers and security professionals/practitioners. Although I will examine their roles while explaining the phases of securitization, I will describe them here to be able to reflect the reason for dividing them into different levels.

What is meant by high-level decision-makers is similar to the concept of the securitizing actor of the Copenhagen School. ${ }^{47}$ In a state, this unit includes higher-level decision-makers, such as the head of the executive, chief of staff or other high-ranking generals, and the defense, interior, foreign affairs ministers, etc. In non-state units, this level may include ethnic, religious, insurgent, or tribal leaders. These high-level decision-makers play a crucial role in defining security and have a significant discursive impact because they have a voice. That is, they can reach their audiences since they have power, and are therefore publicly visible and capable of reaching a mass audience directly, which in turn enables them to convince them via discourses. ${ }^{48}$

On the other hand, security professionals are security practitioners who include operational and tactical actors, such as soldiers, intelligence agents or militants. They mostly only obey the rules and orders and implement the decisions taken at a higher level, acting within the security definitions of the high-level decision-makers. These security professionals have a limited impact on the definition of security. There are staff officers or advisers who can be located at this level. They prepare alternative plans, reports, manuals, and roadmaps for the high-level decision-makers. However, the proportion of this group within security professionals is minimal, and the final decision is not made by them. ${ }^{49}$ Excluding these security professionals, most of the security professionals are security practitioners, and their practices are determined by the decisions of high-level decision-makers. These security practitioners may be aware of what they are doing and its consequences, but they can not decide on their actions with their limited initiative.

However, although these security professionals have a limited effect on the definition of security, they influence the process through their security practices. This role brings a bottom-up character to the process of securitization. Specifically, they help routinize and normalize the security definition determined by the high-level decision-makers. Thus, their expertise is critical. Moreover, because their practices lead to insecurities for different groups and individual human beings, these have to be examined in a securitization analysis.

45 Bigo, "International Political Sociology"; Bigo and Tsoukala, "Understanding (In)Security".

46 Bigo and Tsoukala, "Understanding (In)Security”, p. 5.

47 Buzan et al., Security: A New Framework.

48 I do not deny that the power of these high-level decision-makers is also constructed. However, this constructed power plays a role in the securitization process, so it should also be considered.

49 Although the role of the security professionals in the definition of security is limited, their effect should be examined in a securitization analysis. Moreover, in a different context where there are strong security institutions, this role can be more important. 
Another issue that must be stated here is related to the division between high-level decisionmakers and security professionals. It may be easier to make this division in a state where bureaucratic classifications are clear. However, in non-state actors, it is more complicated. A leader in an armed group may be acting both as a decision-maker and security practitioner. Moreover, the line between high-level decision-makers and security professionals is case-specific and based on contextual issues too. Even in a state, there may be some hybrid roles, which can be considered as both. Therefore the analyst should carefully examine these actors in a dual securitization analysis.

In the Colombian case, the Colombian president and high-level ministers can be seen as the high-level decision-makers for the primary securitization. As for the security professionals, members of the Colombian military can also be regarded as security professionals. For the counter-securitization, the roles in FARC are hybrid since high-level decision-makers are also security practitioners. However, the political leaders and front leaders of FARC can be seen as high-level decision-makers, and its lower-level leaders and militants can be seen as security professionals.

\section{The Phases of Securitization}

This part examines the phases of securitization. As I stated above, the primary aim of this study is to introduce a dual approach for securitization. In this approach, I regard securitization as a process rather than a moment. Clashes between rival voices do not end when a large enough audience has been convinced. Instead, all sides continue their efforts throughout the process. Moreover, the ideas of the audience also do not stay fixed. Audiences may change their stance even after the start of extraordinary measures. There are many instances, including the 2003 War in Iraq, the Vietnam War, or the Colombian conflict when audiences changed their support even after security practices had been implemented. In short, securitization starts by defining security and continues after the implementation of extraordinary means, including clashes between rival definitions, counter moves, implementation of security practices, discursive efforts to convince audiences, routinizations and normalizations through security practices, and insecuritizing consequences. The process only ends when the given issue has been fully desecuritized. For the sake of clarity, I divide the process into three phases: (1) decision/definition, (2) construction and (3) insecuritization-in-action. However, it should be stated that these phases do not necessarily occur in an orderly manner. For example, the security practices that are examined in the second phase are also the same practices that lead to the insecurities for ordinary people that are examined in the third phase. These phases are determined to be able to examine the whole process without missing essential parts of it.

The first phase is the decision/definition phase. As I stated above, the decision/definition is not everything for the construction of a security issue. However, this phase is an important component, as securitization cannot start without a definition. Even if this definition is not always stated publicly, it is determined in people's minds. This definition is made by the high-level decision-makers as introduced above. This security definition is an important factor that indicates the top-down character of the securitization process. However, even in this phase, there are bottom-up characteristics too. While making this decision, high-level decision-makers are influenced by the ideas of the audiences and security professionals. They have to take ideas and feelings of the audience into consideration since, in the end; their consent will determine the success of the securitization process. Moreover, it should be noted that this definition is not stable because the elements of the security definition made in the initial phase of securitization may change in the process of securitization. 
Securitization is not only about determining something as an existential threat. Beyond the determination of the threat, the definition of security involves answering the questions: what exactly is the threat? What is dangerous? What should be protected? Which measures should be used against this threat? Who is the legitimate protector? What can be sacrificed? In other words, the definition includes the determination of threat, referent object, the legitimate security agent, the means that can be used against the threat and the ones that can be sacrificed. As I stated above, all these components of the security definition may not be announced publicly. Particularly the ones that can be sacrificed or the expected and accepted insecurities may be kept secret or may be presented differently. However, these can be captured by the practices of the securitizing actor.

The dual character of the securitization process should be kept in mind in this phase. This definition is only a truth claim, and there are rival truth claims that must be examined in a dual securitization analysis. If there is a counter-securitization, the security definition of this securitization also must be examined. If there is non-violent opposition, their stances and arguments against the security definition must be presented.

In the Colombian case, according to the state, Colombia's communists posed an existential security threat since they were threatening the very existence of the Colombian state. The referent object was the state itself and the Colombian people. The legitimate security agents were the state forces and paramilitaries, while basic rights and, in many cases, the lives of Colombian people could be sacrificed. For the determination of communism as a threat, the external context within the Cold War and the impact of the United States, which regarded the spread of communism as a threat at that time, played a crucial role. ${ }^{50}$ Conversely, FARC defined Yankee Imperialism (the United States) and its "puppet" government in Colombia as the threat, while the referent object was poor Colombians, particularly those living in rural parts of the country. The legitimate security providers were FARC guerrilla forces that could impose the same sacrifices as the state. Both definitions also evolved during the process. ${ }^{51}$ The focus on the United States decreased after the Cold War, when the Colombian state started to be presented as the main threat. ${ }^{52}$ As expressed above, there were also non-violent opposition groups who rejected either or both of the security definitions of the Colombian state and FARC without counter-securitizing the issue.

The second phase is called construction. During this phase, the issue is constructed as an exceptional security problem. To this end, the audience is convinced of the security definition made in the first phase, and this security understanding is normalized and routinized via security practices. During this phase, high-level decision-makers discursively try to convince the audience about the given security definition. Here, I do not have a narrow perception of discourse like Securitization Theory's speech act approach. I believe non-lingual representations like mapping or other visual representations should also be considered within the scope of discourse. These discursive efforts of high-level decision-makers indicate the top-down characteristic of the securitization process.

In addition to these discourses, as a bottom-up characteristic, the practices of security professionals are also crucial since their actions help routinize, normalize, and institutionalize the

50 See Plan Lasso and Alliance for Progress program, Denis M. Rempe, "Guerrillas, Bandits, and Independent Republics: US Counter-Insurgency Efforts in Colombia 1959-1965”, Small Wars \& Insurgencies, Vol. 6, No 3, 1996, p. 304-27

51 FARC Manifesto, 1966, http://cedema.org/ver. php?id=4415 (Accessed 23 April 2020).

52 Baysal, Securitization and Desecuritization of FARC. 
securitization of the issue. As argued above, this is in line with the International Political Sociology approach of the Paris School. These security practices are critical because they may induce the audience, who witnesses or suffers from these security practices, to accept that the given issue is indeed a security issue. The expert status of these security professionals and the repetitions of security practices are crucial for routinizing the securitized issue as defined by the high-level decision-makers in the previous phase. However, one should keep in mind that these practices are limited by the security definition made by high-level decision-makers in the previous phase. The analyst has to keep the dual nature of the securitization process in mind in this phase too. In this phase, rival discourses and practices may clash with each other. The opposition may resist the claims of security made by high-level decision-makers. If there is a counter-securitization, the discourses and practices of both sides clash.

In the Colombian case, Colombian state representatives attempted discursively to convince the Colombian people (the audience) by presenting FARC as a security threat. They mainly focused on FARC's activities that harmed innocent people, such as drug trafficking, suicides, and particularly kidnappings. The following examples from the speeches of ex-president Uribe present this effort:

"One murder is serious enough, ... but we have 34.000. In kidnaps, of which between 3,000 and 3,600 are reported, we account for $60 \%$ of all such crimes in the world. And each kidnap means suffering, the flight of capital, and unemployment.

No crime can have justification. No crime can be justified, directly or otherwise. No kidnap can be explained away by political doctrine. I understand the grief of the mother, the orphan, and the displaced." ${ }^{3}$

Meanwhile, FARC tried to convince the same audience by focusing on atrocities committed by state forces and their links with right-wing paramilitary groups. The following examples are from the Manifesto of FARC that took place in the same period:

"The illegitimacy of the regime and the terror of the state give effect to the popular uprising and validate, before the world, the sacred right of the Colombian people to rebellion.

Today, as it has been for half a century, the owners of power, haciendas ${ }^{54}$, and money organize criminal gangs charged with assaulting the people and sowing terror ... to perpetuate themselves as rulers, nourished with the inexhaustible finances of the drug trade; and conforming thus a paramilitary and mafia state with fascist characteristics.

The so-called political process that is currently underway is demonstrating the deep and solid links between political power, militarism, administrative corruption, and drug trafficking.

The oligarchy wanted to hide the increased power of the mafias entrenched in the state apparatus, to flood narco-dollars to the national market and to achieve impunity for some capos protected by a law approved by the paramilitaries themselves in the parliament with the keen and invaluable help of the national government of Uribe." ${ }^{55}$

53 Ibid

54 Large farms and estates.

55 Manifesto of 9th National Conference of FARC, 2007, http://www.farc-ep.co/octava-conferencia/novena-conferencianacional-de-gue rrilleros.html (Accessed 23 April 2020). 
The security practices of both sides also played an essential role in these constructions since they routinized and normalized their security definitions. For example practices of both sides like roadblocks, implementation of curfews, travel bans, conscription, operations and patrols, and evacuation of villages led to the routinization and normalization of the security definition that was made in the first phase. As stated above, FARC relied more on security practices rather than discursive efforts since its access to means of communication was not as strong as that of the primary securitizing actor.

The final phase, insecuritization-in-action, focuses on how securitization of one issue for one referent object leads to insecurities for other groups and individual human beings. Securitization analysts cannot separate efforts to securitize one issue from its insecuritizing consequences; they should be examined together. Focusing only on one part ignores other critical factors and implications. In particular, security practices of security professionals - whether due to primary securitization or counter-securitization - mostly lead to insecurities for different groups and particularly ordinary people through the killing of civilians, abductions, curfews, increased poverty, forced migration, lack of education, and loss of individual freedoms like freedom of movement, property rights, right for privacy, and freedom of speech, etc.

Since the insecuritization consequences are not explained above, this phase requires more explanation here. In line with another critical security approach, namely the Emancipatory Security approach of the Welsh School, this phase focuses on the insecurities that individual human beings face. The Welsh School takes individual human beings as the primary referent object and regards their emancipation as security. In this understanding, unlike the Copenhagen School, the security of these people is not only related to their survival, but also about their well being. In other words, security threats are not only existential in nature, and other threats that limit the well being of people are also regarded as security issues. In line with this, security is survival-plus; it is not only about life, but also about living. ${ }^{56}$ By introducing this phase and focusing on the insecurities faced by individual human beings, the new framework merges Welsh School and Copenhagen school insights, in addition to feeding from the perspective of the Paris School, by focusing on the practices of security professionals.

Merging the Copenhagen School's Securitization Theory and the Welsh School's Emancipatory Security approach may seem inconsistent, since the Copenhagen School focuses on the constructed nature of security issues while the Welsh School refers to "real" threats directed against "real people, and not the allegedly real ones voiced by the state." ${ }^{57}$ However, I argue that the creators of Securitization Theory do not mean to suggest that individuals or groups don't, in fact, confront objective threats to their survival and security but simply exclude them from the scope of their analysis. Instead, what they wanted to show is how "security" is deployed selectively and discursively, mainly by state actors and sometimes by others. In addition to these, integrating the insecurities faced by the individual human beings also adds to the efforts to bring a normative/ethical stance to the theory of securitization. ${ }^{58}$

56 Ali Diskaya, "Towards a Critical Securitization Theory: The Copenhagen School and Aberystwyth Schools of Security Studies", e-IR, 2013, https://www.e-ir.info/2013/02/01/towards-a-critical-securitization-theory-the-copenhagenand-aberystwyth-schools-of-securitystudies/ (Accessed 20 February 2020), p. 3.

57 Ole Wæver, "Aberystwyth, Paris, Copenhagen: the Europeanness of New "Schools" of Security Theory in an American Field", Arlene B Tickner and David L. Blaney (ed.), Thinking International Relations Differently, Abingdon, Routledge, 2012, p. 52.

58 Rita Floyd, "Can Securitization Theory Be Used in Normative Analysis: Towards a Just Securitization Theory", Security Dialogue, Vol. 42, No 4-5, 2011, p. 247-439; Diskaya, “Towards a Critical Securitization”. 
In the dual securitization of FARC and the Colombian state, both sides created insecurities for ordinary Colombian citizens. In terms of sacrifices, thousands of people were killed, and many more became refugees; many children were used as child fighters while thousands of people were kidnapped for ransom or political purposes. The total number of conflict-related deaths between 1958 and 2012 had reached 220,000. More than 81.5 per cent of those killed were civilians. ${ }^{59}$ In addition to these severe insecurities, people's basic rights and freedoms were also restricted by the dual securitization, including rights to free movement, education, speech, and a free press.

\section{Units of Securitization}

The new framework requires modification of some of the units proposed by Securitization Theory. Since the referent object and functional actors are not modified for the new dual framework, I will not examine them here in detail. The referent object is represented as endangered by the securitized issue. According to Buzan et al., this unit may be limited to human collectivities at the micro-level, a state or tribe or ethnic/religious minority at the middle level or regional or global peace at the macro level. ${ }^{60}$ The functional actors are the elements that influence the securitization process without being a securitizing actor or referent object. This actor is also very crucial since it helps the analyst to examine different aspects of a securitization process in addition to the determined units. Moreover, it is also helpful to focus on one aspect of wider conflicts. For example, one can focus on dual securitization of FARC and the Colombian state in the wider Colombian conflict, which also includes the United States, paramilitaries, and drug cartels.

In addition to referent object and functional actors, the third unit of securitization is the audience. The audience must be convinced to assent to the securitization of an issue. It is a vital component of the process because persuading the audience determines what is accepted as right and legitimate. ${ }^{61}$ According to Balzacq, there are two types of audiences. ${ }^{62}$ These are formal and moral ones. The formal audience is the one, which has to be convinced of the need to take action. It gives formal support to the action, and without this support, no action can be taken. Although it changes according to the context, legislatures can be seen as formal audiences since without their approval governments can not use military forces. The second form of audience is the moral one. This audience provides moral support for the securitization, and their ideas determine what is the right and legitimate definition of security.

In addition, instead of the securitizing actor in Securitization Theory, I use the term high-level decision-makers, who define security and thereby shape the practices of security professionals. They also play an important part in the construction of security through their discursive efforts. Security professionals also need to be regarded as a unit. These practitioners and their actions are crucial for constructing exceptional security issues since they play a significant role in the routinization and normalization of the security definition. Moreover, their practices lead to insecurities for ordinary people.

59 Historical Memory Group, “BASTA YA! Colombia: Memories of War and Dignity”, 2016, Bogotá; Baysal, Securitization and Desecuritization of FARC.

60 Buzan et al., Security: A New Framework.

61 Balzacq, “The Three Faces of Securitization”, p. 173

62 Ibid. 
Since this new framework also analyzes the insecuritizing consequences of the process, those whose security is sacrificed for the sake of securitization should be regarded as another unit, whom I term "sufferers". Sufferers are crucial for the analysis to represent what is sacrificed. In some cases, security professionals can also be regarded as sufferers. This is because their ideas do not affect the definition of security and decision-making at the macro level while suffering during the process (e.g. risk of death, separation from families). This claim is more meaningful when one considers forced recruitments in terrorist organizations, recruitment of minors, compulsory military service, and military values like unconditional obedience.

Finally, the non-violent opposition, such as opposition parties, interest groups, or nongovernmental organizations, must also be regarded as a unit that rejects the high-level decisionmakers' definition of security without implementing counter-securitization. This actor is crucial to show that securitization is not a linear process in which only the high-level decision-makers have a voice. The following table summarizes the units of the dual securitization process.

Table 1 - Units of the Process of Constructing Security

\begin{tabular}{|l|l|l|}
\hline Unit & Explanation & Examples from Colombia/FARC Case \\
\hline Referent Object & $\begin{array}{l}\text { This unit is presented as if being threatened } \\
\text { by the securitized issue and that must be } \\
\text { protected. }\end{array}$ & $\begin{array}{l}\text { Primary Securitization: Colombian State and } \\
\text { Colombian People } \\
\text { Counter-Securitization: Poor people in Colombia, } \\
\text { particularly the ones living in the rural parts. }\end{array}$ \\
\hline Functional Actors & $\begin{array}{l}\text { The actor(s) that influence the securitization } \\
\text { process without being a securitizing actor or } \\
\text { other predetermined units. }\end{array}$ & $\begin{array}{l}\text { Primary Securitization \& Counter-Securitization: } \\
\text { The United States, Paramilitary Groups, Drug } \\
\text { Cartels, other insurgent guerrilla groups like ELN, } \\
\text { Media. }\end{array}$ \\
\hline Audience & $\begin{array}{l}\text { This is the unit that must be convinced about } \\
\text { the security definition. }\end{array}$ & $\begin{array}{l}\text { Primary \& Counter-securitization: Colombian } \\
\text { People, International Community }\end{array}$ \\
\hline $\begin{array}{l}\text { High-Level } \\
\text { Decision Makers }\end{array}$ & $\begin{array}{l}\text { definition and convinces audience(s) with } \\
\text { discursive efforts. }\end{array}$ & $\begin{array}{l}\text { Primary Securitization: Head of the executive, } \\
\text { minister of defense, minister of interior, High } \\
\text { ranking generals } \\
\text { Counter-Securitization: Manual Marulanda (FARC } \\
\text { leader) and high profile FARC leaders }\end{array}$ \\
\hline $\begin{array}{l}\text { Security } \\
\text { Professionals }\end{array}$ & $\begin{array}{l}\text { This is the unit, which implements security } \\
\text { measures and leads to the routinization and } \\
\text { normalization of security. }\end{array}$ & $\begin{array}{l}\text { Primary Securitization: Soldiers and Police officers } \\
\text { (in some cases paramilitary groups) } \\
\text { Counter-Securitization: Guerrillas }\end{array}$ \\
\hline that are insecuritized through security \\
practices.
\end{tabular}

\section{Conclusion}

This study evaluates Securitization Theory, which has been one of the most prominent critical security approaches since it was fully introduced in 1998, and provides a new approach to examine the construction of security issues and their insecuritizing consequences. The new framework builds on the Securitization Theory and addresses some of its limitations. The approach enriches 
the literature on securitization by examining securitization as a process of three phases (decision/ definition, construction, insecuritization-in-action); integrating new units like the opposition, sufferers, high-level decision-makers, and security professionals; providing a dual framework that takes both the opposition and counter-securitizations into consideration and problematizes both sides of the political debate; evaluating the distinct roles of high-level decision-makers and security professionals; deemphasizing the state as the unique or primary securitizing actor and security agent; and considering both the securitization process itself and its insecuritizing consequences.

Additionally, the new dual framework feeds from the insights of the Paris School and the Welsh School by focusing on the practices of security professionals and insecurities for individual human beings. Regarding these critical security approaches not as rivals but as different ways of reaching a broader security understanding with many common parts, the article also contributes to the efforts to build bridges among these three schools of critical security studies. On the other hand, it also helps to eliminate the limitations of the approaches of the Paris School and Welsh School by adding macro-level discursive aspects to the micro-level practice centered approach of the Paris School and introducing a practical tool to reach its emancipatory goals.

The new dual framework can be used in different case studies at different levels and sectors. As designating future avenues of research, the new framework can be utilized to examine internal conflicts like the Colombian case, where both state and the other groups securitize each other, and interstate conflicts where one state securitizes another and the other state responds with a countersecuritization. Moreover, the new framework provides a tool to examine internal opposition and other non-violent rival voices in interstate conflicts. Finally, the dual framework can also be used to examine issues like the securitization of environmental issues and pandemics where there are rival voices about their securitization. As for theoretical future research, a study solely on the role of security professionals and their victimization in the dual securitization process can strengthen the arguments of this study. Additionally, the three-phase framework of the new approach can be further elaborated by linking this to Finnermore and Sikkink's three-phase life cycle of norms. ${ }^{63}$ Particularly the first phase "norm emergence" can be linked to the "decision/definition" phase as both of these focus on the decision maker's motives and decisions. The second phase "norm cascade" can also be linked to the discursive efforts in the "construction" phase as both include widening and legitimization of the decisions made in the first phase. Finally, the third phase "internalization" can be linked to impact of non-discursive practices in the "construction" phase as both of these lead to normalization and routinization of the norms. Both dual securitization framework and Finnermore and Sikkink's three-phase life cycle of norms can benefit from a study that links these two approaches.

63 Martha Finnermore and Kathryn Sikkink, "International Norm Dynamics and Political Change", International Organization, Vol. 52, No 4, 1998, p. 887-917. 